\title{
Analisa Laju Alir Sumur Produksi Berdasarkan Uji Deliverabilitas di Sumur "TY-07" Lapangan KAG
}

\author{
Agustina Prihantini, Yeni Susanty, Nurkhozin Adhi Nugroho \\ Teknik Perminyakan, Akademi Minyak Dan Gas Balongan Indramayu agustinaprihantini@yahoo.co.id
}

\begin{abstract}
Abstrak
Dalam penentuan deliverabilitas suatu sumur gas, dilakukan pengujian terhadap sumur tersebut (multipoint test). Ada 3 metode multipoint test untuk mendapatkan harga Absolute Open Flow Potential (AOFP) yaitu Back Pressure, Isochronal Test, dan Modified Isochronal Test. Untuk mengetahui kemampuan sumur "TY-07" digunakan uji deliverabilitas jenis Modified Isochronal Test. Uji deliverabilitas terdiri dari 4 laju alir gas yang berlangsung selama 4 jam dengan ukuran choke yang berbeda. Dalam penentuan laju produksi digunakan harga rate sebesar $30 \%$ dari AOFP, sedangkan penentuan deliverabilitas menggunakan metode konvensional dengan pendekatan tekanan $\triangle \mathrm{P} 2$ untuk menganalisa deliverabilitas terhadap tekanan reservoir $<2000$ psia. Analisa uji deliverabilitas pada sumur "TY-07" Lapangan KAG dilakukan dengan memplot antara log $\Delta \mathrm{P} 2$ terhadap log qsc dan menghasilkan harga $\mathrm{n}$ dan $\mathrm{C}$, masing-masing sebesar 1 dan 2, 677 x 10-7 MMSCFD/Psi2. Sedangkan nilai AOFP dengan metode konvensional yaitu 5,531 MMSCFD dengan rate produksi optimum ditinjau dari kurva tubing intake untuk ukuran tubing 2,992 inch dan 3,958 inch masing-masing sebesar 2,3 MMSCFD dan 2,7 MMSCFD.
\end{abstract}

Keywords : AOFP, Deliverabilitas sumur gas, Laju alir optimum, Modified Isochronal test

\section{PENDAhuluan}

Ketidakseimbangan tekanan pada reservoir umumnya terjadi karena dibukanya suatu sumur yang menghubungkan permukaan dengan reservoir gas. Akibatnya fluida yang berada di dalam media berpori akan mengalir menuju sumur karena adanya perbedaan gradien tekanan. Gas yang mengalir mempunyai sifat compressible, karena memiliki viskositas rendah yang memungkinkan tidak laminer (aliran viscous), melainkan dipengaruhi oleh unsur inersia dan turbulensi. Hal ini terjadi pada laju produksi dan gradien tekanan yang besar, seperti aliran di dekat lubang sumur.

Pengujian sumur merupakan salah satu hal yang cukup penting dalam merencanakan pengembangan lapangan. Pengujian sumur saat diproduksikan dengan cara membuka sumur untuk jangka waktu tertentu, dan umumnya dimulai pada saat kondisi tekanan reservoir di sekeliling sumur dalam keadaan stabil. Sedangkan pengujian pada saat sumur ditutup maka akan dilakukan pengamatan setelah sumur diproduksikan untuk jangka waktu tertentu.

Berdasarkan latar belakang di atas maka tujuan dari penulisan makalah ini adalah menganalisa laju alir sumur produksi suatu reservoir gas pada Sumur "TY-07" Lapangan KAG yang terletak di Sumatera Selatan yang berdasarkan dari hasil uji Deliverabilitas dan kurva Tubing Intake dengan metode pengujian Modified Isochronal Test yang dipilih berdasarkan karakteristik reservoir yaitu permeabilitas formasi. Hasil dari uji deliverabilitas merupakan parameter penting dalam menentukan laju produksi optimum pada suatu sumur gas, sehingga perlu dilakukan pengujian secara periodik sebagai salah satu penentu ekonomis atau tidaknya suatu sumur.

\section{TINJAUAN PUSTAKA}

\subsection{UJI SUMUR GAS}

Tujuan utama dari pengujian sumur adalah untuk menentukan kemampuan suatu lapisan atau formasi untuk berproduks [1]. Prinsip dasar dari pengujian sumur adalah memberikan suatu gangguan keseimbangan tekanan terhadap sumur yang diuji. Dengan adanya gangguan ini, perubahan tekanan akan disebarkan ke seluruh reservoir dan dapat diamati setiap saat dengan melakukan pencatatan tekanan lubang bor selama pengujian sumur berlangsung. Apabila perubahan tekanan tersebut diplot dengan suatu fungsi waktu, maka akan didapatkan analisa pola aliran yang terjadi dan karakteristik formasi [2].

Uji sumur yang pertama adalah uji deliverabilitas termasuk back pressure test dan isochronal test dengan tujuan untuk mengetahui penurunan tekanan dasar sumur sehubungan dengan laju produksi di kepala sumur pada suatu sumur. Uji sumur yang kedua adalah pressure test (pressure drawdown dan pressure built up) dengan tujuan untuk mengetahui karakteristik reservoir disekitar lubang sumur seperti permeabilitas, ketebalan formasi, faktor skin, faktor high velocity, dan wellbore storage capacity [1]. 
Uji deliverabilitas mengacu pada pengujian sumur gas untuk mengukur kemampuan produksi di bawah kondisi reservoir tertentu dan bottom hole flowing pressure (BHFP). Pada umumnya indikator produktifitas diperoleh dari tes ini adalah Absolute Open Flow (AOF) potential. AOF merupakan rate maksimum dimana sebuah aliran sumur terhadap tekanan balik teoritis atmosfer di sandface tersebut. Pada tahun 1935, Rawlins dan Schellhardt memperkenalkan sebuah hubungan empiris yang sering digunakan dalam analisa uji deliverabilitas yang hanya berlaku pada tekanan rendah [3]. Dengan mengeplot $\Delta \mathrm{p} 2=\left(\bar{p}_{R}{ }^{2}-p_{\mathrm{wf}}{ }^{2}\right)^{\mathrm{n}}$ vs qsc dalam skala log-log akan menghasilkan sebuah garis lurus dimana akan didapatkan slope atau 1/ n. Contoh kurva seperti pada Gambar 1. Persamaan tersebut dapat ditulis dalam bentuk Persamaan $1[4]$ :

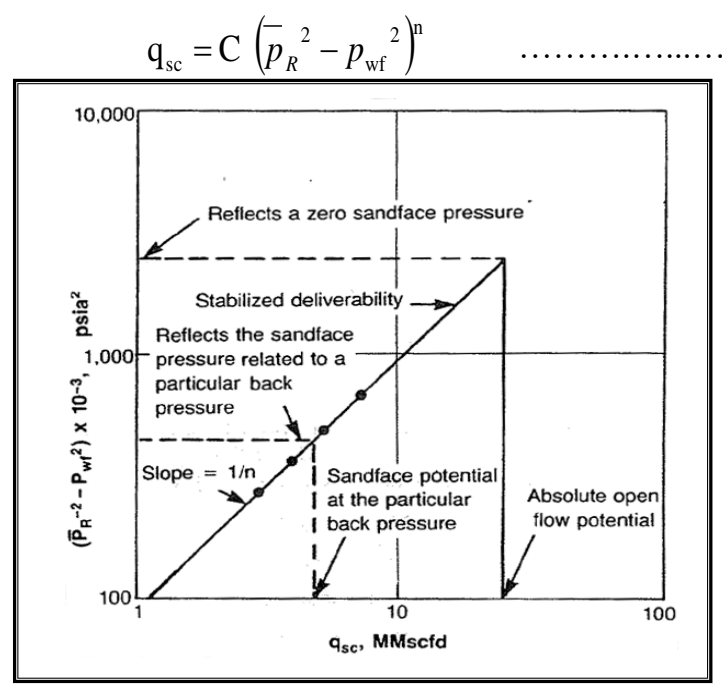

Gambar 1. Plot Uji Deliverabilitas

Secara ideal garis lurus tersebut mempunyai slope atau kemiringan $45^{\circ}$ pada laju produksi rendah dan akan memberikan slope yang lebih besar pada laju produksi yang tinggi. Hal ini terjadi dari naiknya turbulensi di sekitar lubang bor dan perubahan skin factor akibat meningkatnya laju produksi [1].

Harga " $n$ " adalah parameter yang mencerminkan derajat pengaruh inersia turbulensi pada aliran gas. Harga " $n$ " sama dengan 1 berarti pola aliran yang terbentuk adalah laminar, dan harga " $n$ " yang lebih kecil dari 1 maka faktor inersia turbulensi turut berperan (harga " $n$ " dibatasi paling kecil 0.5). Berdasarkan persamaan 1, maka bila dibuat kurva dalam sistem koordinat log-log, maka diperoleh hubungan linier sebagai berikut [5] :

$\log \mathrm{q}_{\mathrm{sc}}=\log \mathrm{C}+\mathrm{n} \log \Delta \mathrm{p}^{2}$.

Dimana :

$$
\Delta \mathrm{P}^{2}=\left(\bar{p}_{R}{ }^{2}-p_{\mathrm{wf}}{ }^{2}\right)
$$

Jika $\left(\bar{p}_{R}{ }^{2}-p_{\mathrm{wf}}{ }^{2}\right)$ merupakan variabel bebas, secara matematika maka kemiringan pada Persamaan 1 adalah n. Namun pada prakteknya, secara umum untuk mengeplot hasil test pada sumur gas, q dianggap sebagai independent variable dan $\left(\bar{p}_{R}{ }^{2}-p_{\mathrm{wf}}{ }^{2}\right)$ adalah variabel terbatas. Dalam keadaan ini kemiringan adalah $1 / \mathrm{n}$. Nilai $\mathrm{n}$ dapat ditentukan dengan persamaan di bawah ini [6]:

$$
\mathrm{n}=\frac{\log \mathrm{q}_{2}-\log \mathrm{q}_{1}}{\log \left(\bar{p}_{R}{ }^{2}-{p_{\mathrm{wf}}}^{2}\right)_{2}-\log \left(\overline{\bar{p}}_{R}{ }^{2}-{p_{\mathrm{wf}}}^{2}\right)_{1}}
$$

Secara grafis, nilai koefisien $\mathrm{C}$ dapat ditentukan dengan ekstrapolasi kurva performance sampai harga $\left(\bar{p}_{R}{ }^{2}-p_{\mathrm{wf}}{ }^{2}\right)$ adalah 1. Pada titik tersebut, nilai $\mathrm{C}$ sama dengan rate aliran. Nilai C dapat ditentukan dengan Persamaan 2 [6]. Besarnya harga AOFP adalah sama dengan harga $\mathrm{q}_{\mathrm{sc}}$ pada harga $\mathrm{P}_{\mathrm{wf}}$ sebesar tekanan atmosfer $( \pm 14.7 \mathrm{psia})[1]$.

$$
\mathrm{AOFP}=\mathrm{C}\left(\bar{p}_{R}{ }^{2}-14.7^{2}\right)^{\mathrm{n}}
$$

\subsection{MODIFIED ISOCHRONAL TEST}

Isochronal dan modified isochronal test dikembangkan untuk pengujian waktu yang pendek yang mana membutuhkan periode yang lama untuk stabil [3]. Prosedur modified isochronal test diperkenalkan pada waktu pengaliran yang pendek yang mana diperlukan dalam uji sumur. Prosedurnya sangat mirip dengan isochronal test, kecuali periode penutupan antara masing-masing flow rate tidak cukup panjang yang memungkinkan sumur kembali ke tekanan reservoir awal rata-rata [4]. 
Dalam modified isochronal test sumur ditutup dengan waktu sama panjangnya yang mana dimungkinkan aliran untuk masing-masing ukuran choke. Selama ini pressure static sumur akan diubah kembali untuk beberapa harga $\mathrm{P}_{\mathrm{ws}}$ yang akan lebih rendah setelah setiap periode aliran. Kelakuan rate aliran dan tekanan dengan waktu ditunjukkan pada Gambar 2 [4].

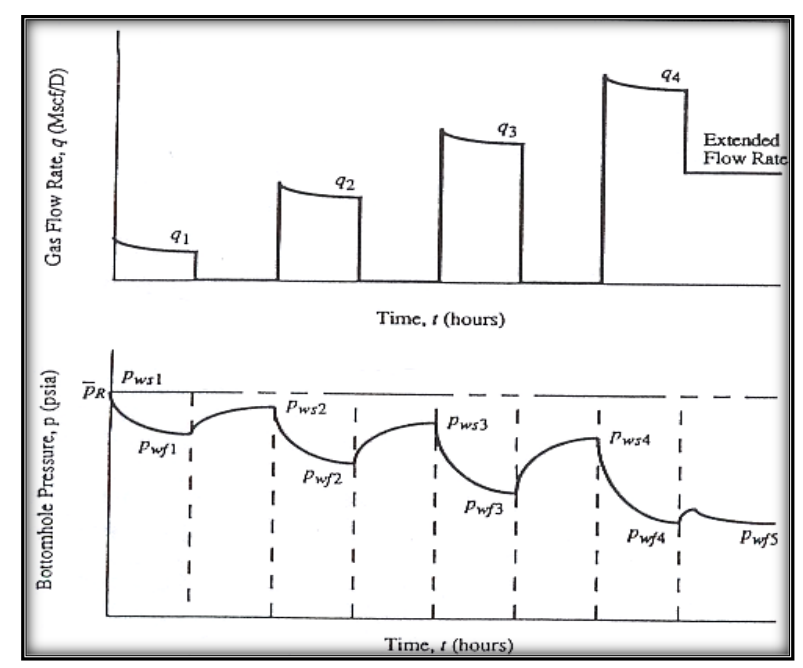

Gambar 2. Modified Isochronal Test

Dalam pengolahan data untuk analisa deliverabilitas untuk harga $\mathrm{P}_{\mathrm{R}}$ digantikan dengan $\mathrm{P}_{\mathrm{ws}}$, dimana harga tekanan yang dibaca pada akhir dari setiap masa penutupan sumur. Dari Gambar 2, terlihat bahwa untuk suatu harga q diperoleh pasangan $\Delta \mathrm{p}^{2}$ atau $\Delta \psi$ dengan kondisi sebagai berikut :

$$
\begin{aligned}
& \mathrm{q}_{1}=\left(\mathrm{P}_{\mathrm{ws} 1}\right)^{2}-\left(\mathrm{P}_{\mathrm{wf} 1}\right)^{2} \\
& \mathrm{q}_{2}=\left(\mathrm{P}_{\mathrm{ws} 2}\right)^{2}-\left(\mathrm{P}_{\mathrm{wf} 2}\right)^{2} \\
& \mathrm{q}_{3}=\left(\mathrm{P}_{\mathrm{ws} 3}\right)^{2}-\left(\mathrm{P}_{\mathrm{wf} 3}\right)^{2} \\
& \mathrm{q}_{4}=\left(\mathrm{P}_{\mathrm{ws} 4}\right)^{2}-\left(\mathrm{P}_{\mathrm{wf} 4}\right)^{2}
\end{aligned}
$$

Sedangkan pengolahan kurva deliverabilitas yang stabil diperoleh dengan jalan menggambarkan sebuah garis sejajar yang melalui $\left(\mathrm{P}_{\mathrm{ws}}^{2}-\mathrm{P}_{\mathrm{wf}}^{2}\right)[5]$.

\subsection{KURVA INFLOW PERFORMANCE RELATIONSHIP (IPR)}

IPR untuk sumur gas tidak linear karena inflow rate merupakan fungsi dari Pwf2. Untuk reservoir dry gas maupun wet gas yang mana bukan kondensasi cairan dalam reservoir, oleh sebab itu saturasi gas dan permeabilitas gas akan konstan sebagai penurunan PR. Jika ada aliran turbulen, penurunan tekanan akan disebabkan oleh turbulensi dan dengan meningkatnya laju alir akan menyebabkan penurunan dalam inflow performance [6].

Persamaan 1 adalah salah satu metode yang umumnya digunakan untuk mendeskripsikan kurva downhole performance. Data yang dipersiapkan untuk kurva performance ini diperoleh dari pengujian 4 titik atau back-pressure test. Kemudian Dari kurva Gambar 1 maka bisa dibuat plot kembali pada kertas koordinat kartesian seperti yang ditunjukkan pada Gambar 3 Yang merupakan inflow performance relationship untuk gas [7].

Pada Gambar 3 ditunjukkan bahwa semakin lama sumur berproduksi maka semakin turun tekanan reservoirnya, sehingga kurva IPR untuk suatu sumur berubah dengan berjalannya waktu. Dengan demikian maka kurva IPR dapat digunakan untuk memprediksi produksi di masa yang akan datang dalam kondisi reservoir, disamping itu juga untuk mengevaluasi potensi deliverabilitas sumur di bawah kondisi permukaan yang bervariasi [5].

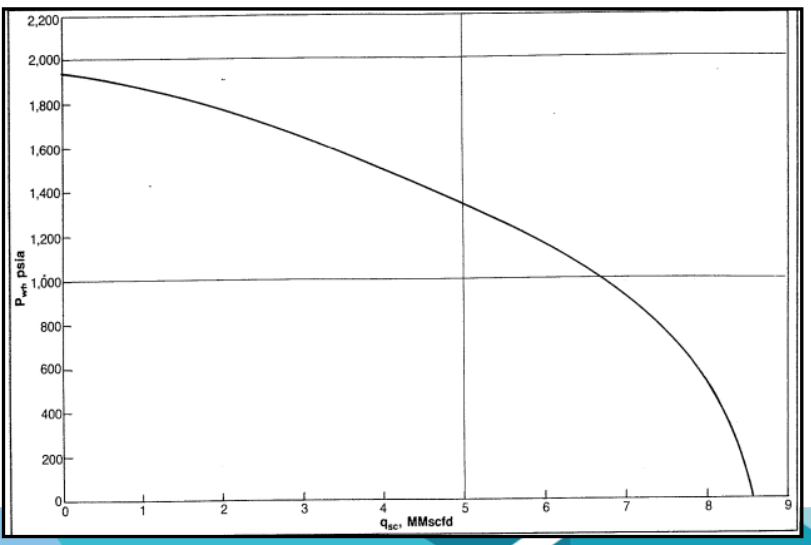




\subsection{KURVA TUBING INTAKE}

Kurva performance tubing merupakan plot antara flowing bottom-hole pressure (Pwf) yang diperlukan sumur gas untuk berproduksi pada beberapa variasi laju gas (qsc) yang melalui beberapa ukuran tubing string pada tekanan aliran kepala sumur (Pwh) yang konstan [7].

Pembuatan kurva tubing intake dengan tujuan untuk menentukan kemampuan berproduksi sumur gas secara alamiah. Besarnya laju produksi sumur gas ditunjukkan oleh perpotongan antara kurva tubing intake dengan kurva IPR, seperti pada Gambar 4. Kurva tubing intake dibuat dengan menggunakan grafik pressure traverse dari Cullender-Smith [4].

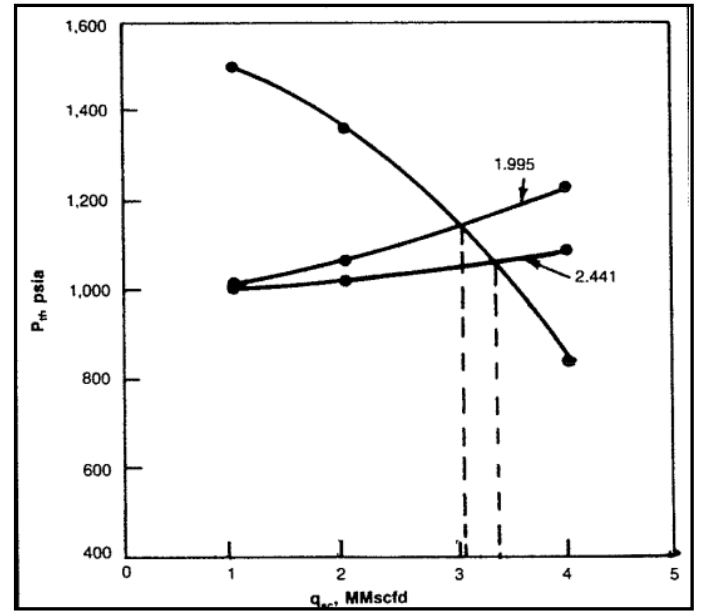

Gambar 4. Kurva Tubing Intake

\section{METODE PENELITIAN}

\subsection{PENENTUAN DELIVERABILITAS SUMUR DENGAN METODE KONVENSIONAL}

Untuk mengetahui kemampuan sumur berproduksi terhadap sumur "TY-07" Lapangan KAG, maka telah dilakukan serangkaian uji Deliverabilitas. Pengujian tersebut dilakukan pada komplesi tubing 3 1 12 inch dengan kedalaman perforasi 1728-1748 mMd dan temperatur reservoir sebesar $228.68{ }^{\circ} \mathrm{F}$. Uji deliverabilitas yang dilakukan adalah Modified Isochronal Test dan pengujian yang dilakukan sebanyak 4 laju alir dengan membuka choke berbagai ukuran yang berbeda. Dimana waktu pembukaan dan penutupan sumur yaitu selama 4 jam dan rangkaian akhir dari pengujian ini yaitu penutupan selama 8 jam.

Metode analisis yang dapat diaplikasikan untuk menentukan parameter deliverabilitas ini dengan menggunakan metode konvensional (Analisis Rawlins-Schellhardt) yang berdasarkan pertimbangan pendekatan tekanan pada hasil record test pada pengujian sumur yang menunjukkan bahwa tekanan reservoir kurang dari 2000 Psi. Setelah mendapatkan data hasil pengujian sumur seperti pada Tabel 1, dan interpretasi data Modified Isochronal test dapat dilihat dari hasil plot antara row pressure dan elapsed time hasil record data sumur "TY-07" Lapangan KAG seperti pada Gambar 5.

Tabel 1 Data Modified Isochronal Test

\begin{tabular}{|c|c|c|c|}
\hline Tanggal, Hari & Jam & Jepitan & Q \\
\hline 9 Januari 2016, Sabtu & $19.00-23.00$ & $11 \mathrm{~mm}$ & 1.9653 \\
\hline $\begin{array}{c}\text { 9 Januari 2016 } \\
\text { Sabtu-Minggu }\end{array}$ & $23.00-03.00$ & Shut in & 0 \\
\hline 10 Januari 2016, Minggu & $03.00-07.00$ & $13 \mathrm{~mm}$ & 2.32 \\
\hline 10 Januari 2016, Minggu & $07.00-11.00$ & Shut in & 0 \\
\hline 10 Januari 2016, Minggu & $11.00-15.00$ & $15 \mathrm{~mm}$ & 2.8964 \\
\hline 10 Januari 2016, Minggu & $15.00-19.00$ & Shut in & 0 \\
\hline 10 Januari 2016, Minggu & $19.00-23.00$ & $17 \mathrm{~mm}$ & 3.176 \\
\hline $\begin{array}{c}\text { 10-11 Januari 2016 } \\
\text { Minggu-Senin }\end{array}$ & $23.00-07.00$ & $13 \mathrm{~mm}$ & 2.9016 \\
\hline
\end{tabular}

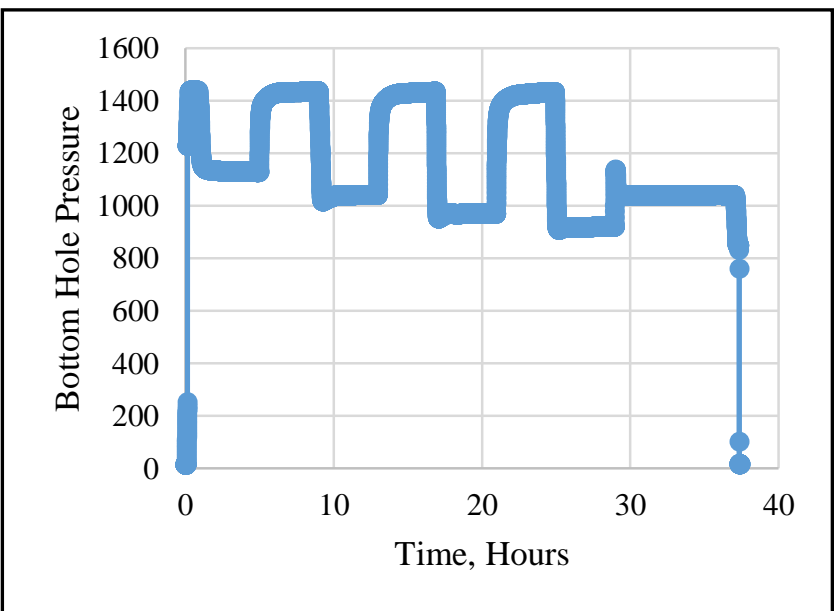


Kemudian untuk menganalisis hasil uji deliverabilitas terlebih dahulu membuat tabulasi seperti pada Tabel 2.

Tabel 2. Pengolahan Data Modified Isochronal Test

\begin{tabular}{|c|c|c|c|c|}
\hline $\begin{array}{c}\text { Pwf } \\
\text { (Psi) }\end{array}$ & $\begin{array}{c}\mathbf{Q} \\
(\mathbf{M M s c f} \\
\mathbf{D})\end{array}$ & $\begin{array}{c}\mathbf{P w s}^{\mathbf{2}} \\
\mathbf{( P s i}^{\mathbf{2}} \mathbf{)}\end{array}$ & $\begin{array}{c}\mathbf{P w f}^{\mathbf{2}} \\
\mathbf{( P s i}^{\mathbf{2}} \mathbf{)}\end{array}$ & $\begin{array}{c}\mathbf{P w s}^{\mathbf{2}} \mathbf{- P w f} \\
\mathbf{( P s i}^{\mathbf{2}} \mathbf{}\end{array}$ \\
\hline 1129.211 & 1.965 & 2065842.788 & 1275117.483 & 790725.306 \\
\hline 1040.842 & 2.320 & 2051090.859 & 1083352.069 & 967738.790 \\
\hline 921.435 & 3.176 & 2051606.470 & 849042.459 & 1202564.010 \\
\hline 991.030 & 2.902 & 2065842.788 & 982140.461 & 1083702.328 \\
\hline
\end{tabular}

Selanjutnya membuat kurva log - log dengan memplot antara $\mathrm{Pws}^{2}$ - $\mathrm{Pwf}^{2}$ dengan Qg yang ditunjukkan seperti pada Gambar 6. Berdasarkan Persamaan 3 dan menarik garis linier pada titik-titik isochronal, maka akan diperoleh harga n. Dan perlu ketahui bahwa harga $\mathrm{n}$ hanya berkisar antara 0.5 sampai dengan 1, Sedangkan untuk menentukan koefisien performa (Performance Factor) yang menggambarkan posisi kurva deliverabilitas yang stabil maka digunakan Persamaan

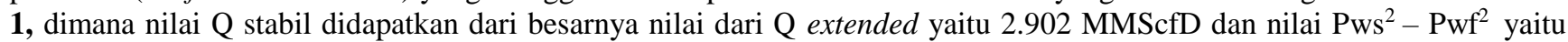
$1083702.328 \mathrm{psi}^{2}$.

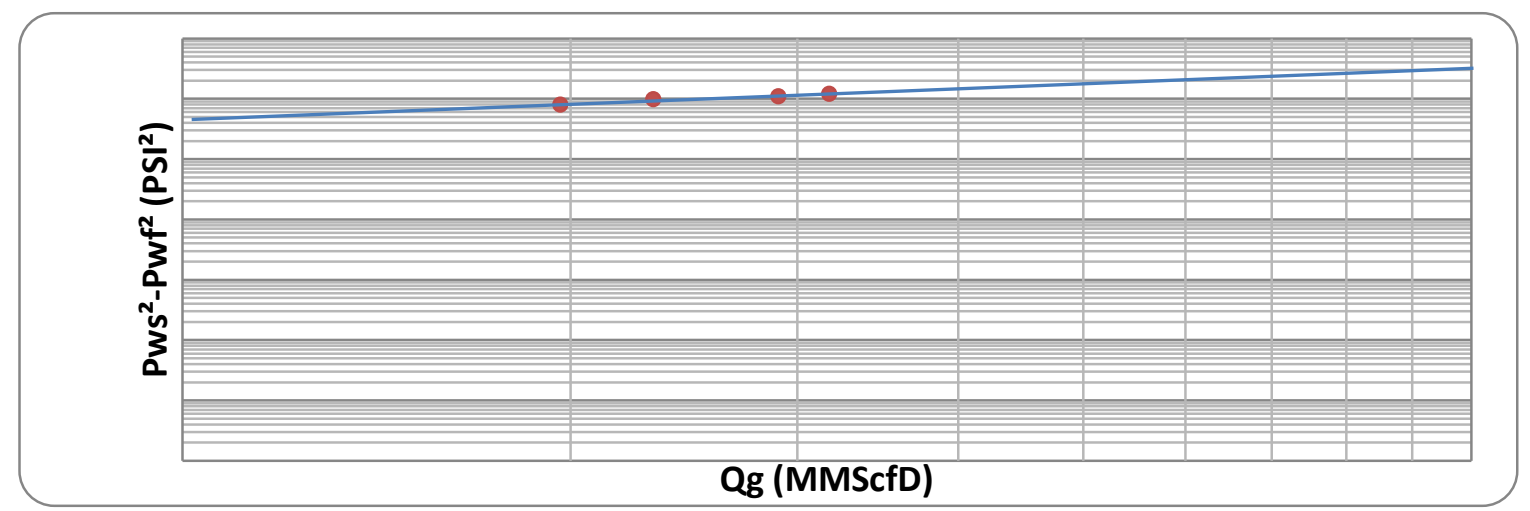

Gambar 6. Kurva Antara Log Pws'2-Pwf ${ }^{2}$ Vs Log Qg

\subsection{PENENTUAN AOFP SUMUR “TY-07” LAPANGAN KAG}

Setelah mendapatkan nilai n (bilangan komponen) dan C (koefisien performa / Performance Factor), maka dapat ditentukan indikator deliverabilitas sumur gas yaitu Absolute Open Flow Potential yang merupakan kemampuan sumur gas untuk berproduksi dengan laju alir maksimum dan besarnya harga AOFP sama dengan harga Qsc pada harga tekanan dasar sumur (Pwf) sebesar $0 \mathrm{~atm}$ atau 14.7 psi. AOFP dapat diperoleh dari pembacaan harga Qsc pada harga Pws ${ }^{2}-14.7^{2}$, dan Pws $^{2}$ yang digunakan saat Qsc yaitu 2065842.788 $\mathrm{Psi}^{2}$. Kemudian dengan mensubstitusikan nilai C, n menggunakan Persamaan 4 maka harga AOFP akan didapatkan.

\subsection{PENENTUAN LAJU ALIR OPTIMUM SUMUR “TY-07” LAPANGAN KAG}

Kurva Inflow Performance Relationship digunakan untuk sebagai forecast performa suatu sumur dimasa yang akan datang. Metode Fetkovich yang digunakan dalam pembuatan kurva IPR ini adalah dengan membuat asumsi beberapa harga Pwf, lalu digunakan untuk mencari variasi harga Qg dengan menggunakan metode analisa konvensional, seperti pada Tabel 3.

Tabel 3 Data IPR

\begin{tabular}{|c|c|}
\hline Pwf assumsi (Psi) & Qg (MMscfD) \\
\hline 1437.304 & 0 \\
\hline 1300 & 1.006 \\
\hline 1200 & 1.676 \\
\hline 1100 & 2.292 \\
\hline 1000 & 2.854 \\
\hline 900 & 3.363 \\
\hline 800 & 3.818 \\
\hline 700 & 4.219 \\
\hline 600 & 4.567 \\
\hline 500 & 4.862 \\
\hline 400 & 5.103 \\
\hline 300 & 5.290 \\
\hline
\end{tabular}




\begin{tabular}{|c|c|}
\hline 200 & 5.424 \\
\hline 100 & 5.504 \\
\hline 0 & 5.531 \\
\hline
\end{tabular}

Lalu plot variabel Pwf dan Qg (dengan data tabulasi Tabel 3) tersebut untuk menggambarkan kurva Inflow Performance Relationship seperti pada Gambar 8. Harga Qg diperoleh dengan menggunakan persamaan empiris deliverablitas dengan metode analisa konvensional dimana Pwf asumsi yang dipakai untuk mendapatkan nilai Qg. Kemudian plot Pwf asumsi di sumbu absis dan Qg di sumbu ordinat.

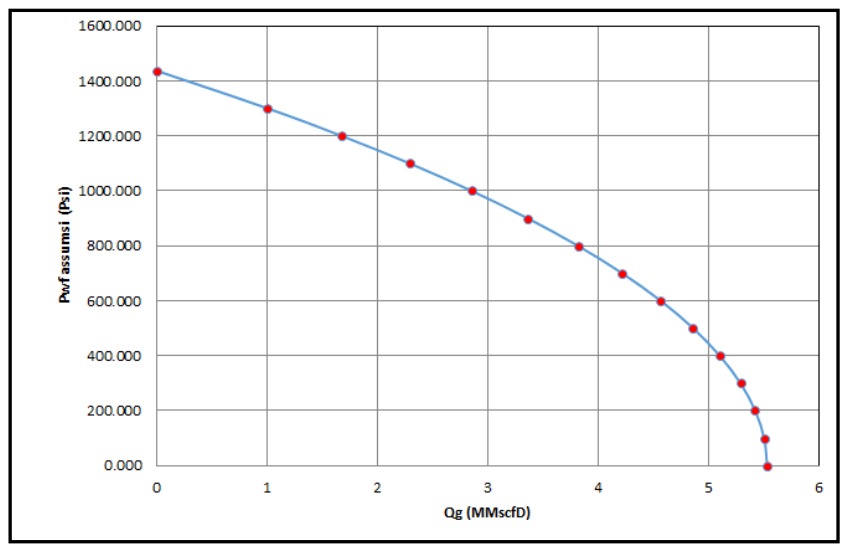

Gambar 8. Kurva Inflow Performance Relationship

Dalam menentukan laju alir optimum sumur gas “TY-07” Lapangan KAG dapat dilakukan dengan memplot silang antara kurva IPR yang telah dikembangkan sebelumnya dengan kurva TPR. Dimana hasil plot antara kedua kurva tersebut dinamakan kurva tubing intake. Pembuatan kurva TPR ini dilakukan terhadap beberapa ukuran tubing yang masing-masing berukuran 2.992 inch dan 3.958 inch. Tubing ditempatkan pada kedalaman 1633 meter atau sama dengan 5356.24 feet. Dengan menggunakan grafik pressure traverse, maka perhitungan tekanan alir dasar sumur pada berbagai laju alir dengan metode penurunan tekanan pada pipa tegak yang dikembangkan oleh Cullender and Smith dapat dilakukan untuk kedua ukuran tubing tersebut.

Setelah itu mengasumsikan beberapa variasi laju alir dan menentukan Pwf dengan menggunakan grafik pressure traverse. Hal ini dilakukan untuk setiap ukuran tubing. Kemudian tabulasikan hasil seperti pada Tabel 4. Hasil perhitungan outflow untuk kedua ukuran tubing dapat dilihat pada Tabel 4. Bila diplot antara Pwf dan Q dari tabel tersebut pada kurva IPR, maka akan membentuk kurva tubing intake. Perpotongan kedua kurva tersebut merupakan laju alir optimum yang dimungkinkan untuk setiap ukuran tubing.

Tabel 4 Pwf Berbagai Ukuran Tubing

\begin{tabular}{|c|c|c|}
\hline \multirow{2}{*}{$\begin{array}{c}\text { Qass } \\
\text { (MMscfD) }\end{array}$} & \multicolumn{2}{|c|}{ Pwf (Psi) } \\
\cline { 2 - 3 } & $\mathbf{d = 2 , 9 9 2}$ & $\mathbf{d = 3 , 9 5 8}$ \\
\hline 1 & 1016 & 1006 \\
\hline 2 & 1062 & 1022 \\
\hline 3 & 1134 & 1049 \\
\hline 4 & 1227 & 1085 \\
\hline
\end{tabular}

\section{HASIL DAN PEMBAHASAN}

Tujuan utama dilakukan pengujian ini terhadap Sumur "TY-07" Lapangan KAG yaitu untuk memprediksi atau memperkirakan kemampuan produksi sumur tersebut atau yang lebih dikenal dengan Deliverabilitas. Jenis uji deliverabilitas yang telah dioperasikan pada sumur tersebut yaitu adalah Modified Isochronal Test. Pengujian Modified Isochronal Test dilakukan sebanyak 4 laju alir dengan membuka choke pada ukuran yang berbeda. Dimana waktu pembukaan dan penutupan sumur yaitu selama 4 jam. Rangkaian akhir dari pengujian ini yaitu penutupan sumur selama 8 jam.

Berdasarkan plot antara Pws2 - Pwf2 dengan Qg pada kurva log-log seperti pada Gambar 6, dalam menentukan harga $\mathrm{n}$ dengan mengambil dua titik diantara titik - titik isochronal pada garis linier, yang kemudian ditarik ke bawah ke sumbu ordinat $\mathrm{Q}$ dan ditarik ke kiri ke sumbu absis (Pws2 - Pwf2) sehingga didapatkan nilai Q2 = 3, Q1 = 2, (Pws2 - Pwf2)2 = 1200000 dan $($ Pws2 - Pwf2)1 = 800000. Dengan menggunakan Persamaan 3 maka diperoleh harga $\mathrm{n}$ sebesar 1.00 dan memenuhi kriteria harga $n$ yang hanya berkisar antara 0.5 sampai dengan 1. Sedangkan harga $\mathrm{C}$ sebesar 2.677x10-6 MMScfD/Psi2. Dari harga $\mathrm{n}$ yang didapatkan mencerminkan bahwa terjadi pembentukan aliran laminer pada aliran gas antara 1.965 MMScfD sampai dengan 3.176 MMScfD. Dengan mensubtitusikan harga Pwf sama dengan 0 atau 14.7 Psi 

7.

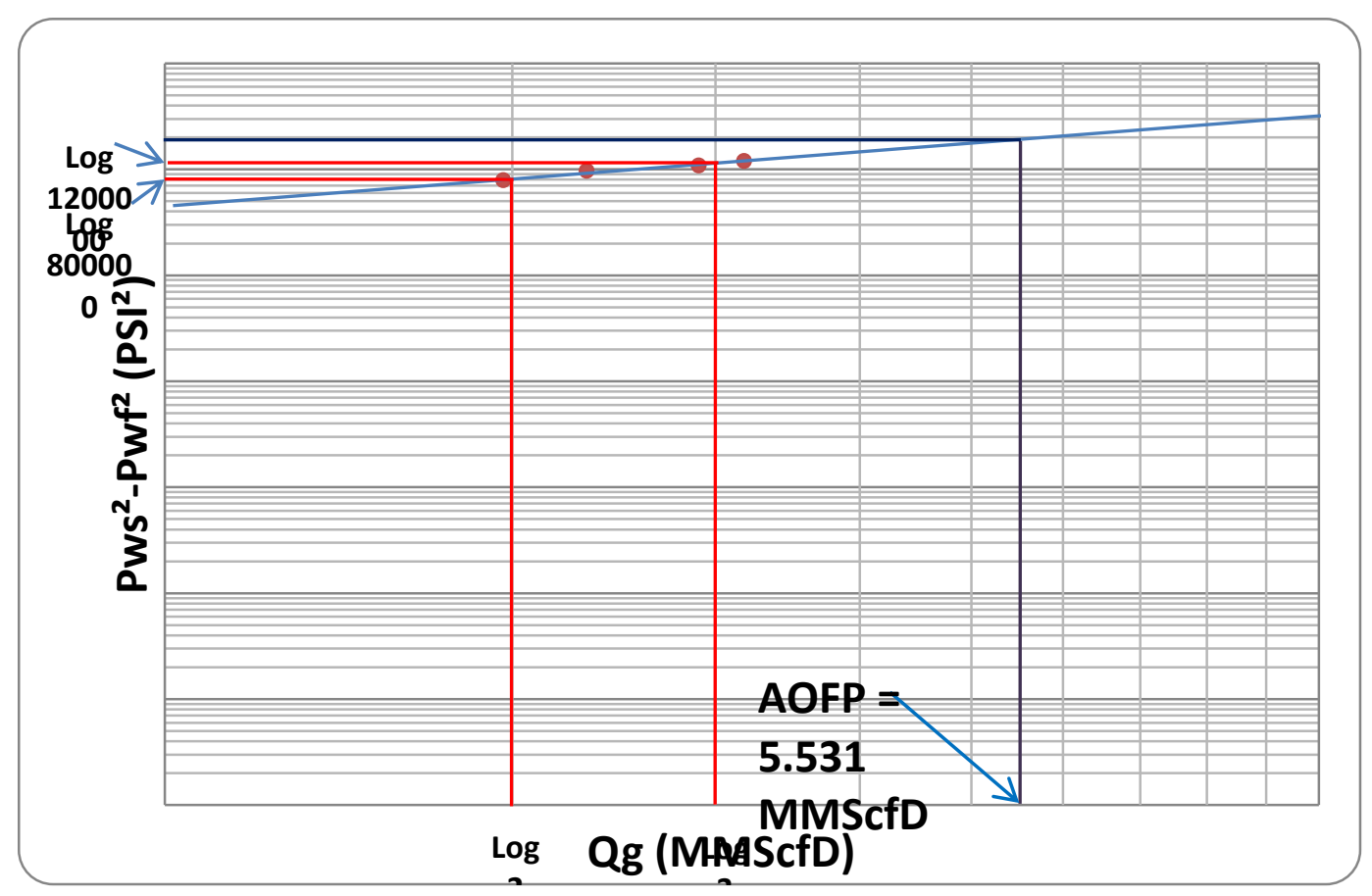

Gambar 7. Kurva Antara Log Pws $^{2}-P_{w f}^{2}$ Vs $\log$ Qg Dalam Penentuan n dan AOFP

Kurva IPR yang dimaksudkan sebagai forecast performance dari sumur "TY-07" Lapangan KAG yang menggambarkan perkiraan kinerja aliran gas dari reservoir ke lubang sumur. Gambar 8. menunjukkan bahwa terjadinya penurunan tekanan laju alir dasar sumur akan meningkatkan laju alir gas. Laju alir gas maksimum diperoleh ketika tekanan alir dasar sumur sama dengan nol sebesar 5.531 MMScfD yang sama artinya dengan AOFP.

Dari Gambar 9 kurva tubing intake didapatkan besarnya harga laju produksi gas optimum yang melalui perpotongan kurva Inflow Performance Relationship dengan Tubing Intake Performance untuk tubing ukuran 2.992 inch sebesar 2.3 MMScfD dan ukuran tubing 3.985 inch sebesar 2.7 MMScfD.

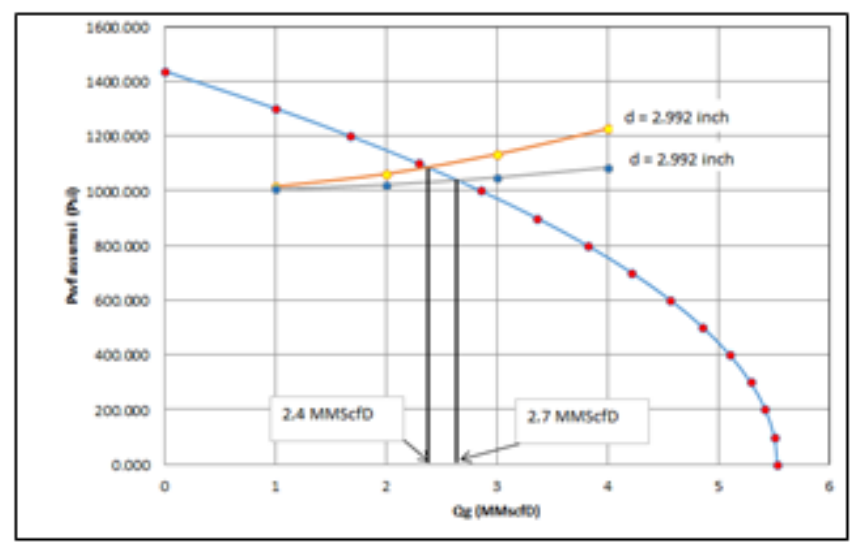

Gambar 9. Kurva Tubing Intake Performance

Dari kurva tubing intake diperoleh laju alir optimum gas Dari hasil tersebut sehingga dapat disimpulkan bahwa semakin besar ukuran tubing maka laju alir gasnya semakin besar pula. Hal ini disebabkan karena semakin besar ukuran tubing maka penurunan tekanan (pressure drop) sepanjang tubing akan semakin kecil yang ditunjukkan oleh semakin kecilnya tekanan alir dasar sumur. Dengan demikian analogi dari kurva IPR mendeskripsikan hubungan antara laju alir gas yang semakin tinggi sedangkan tekanan alir dasar sumur semakin kecil.

\section{KESIMPULAN}

1 Berdasarkan hasil analisis uji deliverabilitas diperoleh harga $\mathrm{n}$ sebesar 1 yang menunjukkan jenis aliran gas yang terbentuk adalah laminer.

2 Harga C yang diperoleh yaitu sebesar $2.677 \times 10^{-6} \mathrm{MMScfD} / \mathrm{Psi}{ }^{2}$.

3 Harga AOFP yang diperoleh sebesar 5.531 MMScfD.

4 Laju alir optimum sumur "TY-07" Lapangan KAG sebesar 2.3 MMscfD pada tubing ukuran 2.992 inch dan 2.7 MMscfD pada tubing ukuran 3.985 inch. 
5 Semakin besar ukuran tubing maka laju alir gasnya semakin besar pula tetapi tekanan alir dasar sumur akan semakin kecil.

\section{SIMBOL}

$\mathrm{P}_{\mathrm{ws}} \quad=$ Tekanan dasar sumur, psi

$\mathrm{P}_{\mathrm{i}} \quad=$ Tekanan mula-mula reservoir, psi

$\bar{p}_{R} \quad=$ Tekanan rata-rata reservoir, psia.

$\mathrm{p}_{\mathrm{wf}} \quad=$ Tekanan alir dasar sumur, psia.

$\mathrm{Q} \quad=$ Laju produksi sebelum sumur ditutup

$q_{s c} \quad=$ Laju aliran gas, Mscf $/ \mathrm{d}$

$\mathrm{C}=$ Koefisien performance yang menggambarkan posisi kurva deliverabilitas yang stabil, Mscfd/psia ${ }^{2}$

$N \quad=$ Bilangan eksponen, merupakan inverse slope dari garis kurva deliverabilitas yang stabil dan mencerminkan derajat pengaruh faktor inersia-turbulensi terhadap aliran, umumnya berharga antara 0.5-1 atau $n=\tan \theta$

$\mathrm{T} \quad=$ Temperatur dasar sumur, ${ }^{0} \mathrm{~F}$.

\section{DAFTAR PUSTAKA}

[1] D. V. Rukmana, Dadang; Kristanto, Dedy; Cahyoko Aji, Teknik Reservoir"'Teori dan Aplikasi”. Yogyakarta: Pohon Cahaya, 2011.

[2] T. Wibowo, Deddy Surya; Ariadji, "Desain Waktu Buka Sumur Uji Back Pressure Pada Sumur Minyak Sembur Alami untuk Memberikan Hasil Permeabilitas yang Lebih Akurat,” JTM, vol. XVI, no. 4, 2009.

[3] J. Lee, Gas Reservoir Engineering. Richardson. TX, 1996.

[4] D. H. Beggs, Gas Production Operations. Oklahoma: OGCI Inc, 1984.

[5] E. M. Tobing, "Perkiraan laju Alir Optimum Gas Dengan Analisis Nodal," Pus. Penelit. dan Pengemb. Teknol. Miny. dan Gas Bumi, vol. 11, no. 1, 2013.

[6] D. H. Beggs, Production Optimization Using Nodal TM Analysis. Oklahoma: Tulsa, 1995.

[7] C. U. Ikoku, Natural Gas Production Engineering. USA: The Pennsylvania State University, 1992. 